\title{
Monitoring after the conclusion of mining works
}

\section{Monitoring po opustitvi rudarskih del}

\author{
Tomaž Hribar ${ }^{1, *}$, Tomaž Pečolar', Goran Vižintin² \\ ${ }^{1}$ Institute for Mining, Geotechnology and Environment, Slovenčeva 93, 1000 Ljubljana, Slovenija \\ ${ }^{2}$ University of Ljubljana, Faculty of Natural Sciences and Engineering, Aškerčeva 12, 1000 Ljubljana, Slovenija \\ *tomaz.hribar@irgo.si
}

\begin{abstract}
After mining works are completed and the mine is permanently closed, the holder of the mining rights must carry out monitoring in accordance with the applicable legislation and for the purpose of controlling the extraction area. This includes monitoring of the changes that have occurred during the process of mining, both on the surface and below it. This article presents an example of a monitoring program after the mining works are completed. The extraction of raw mineral material in an underground mine results in various impacts on the surface and underground space. The areas or segments of monitoring are divided into two parts in this article: The underground part includes monitoring of the geomechanical, climatic, and hydrogeological changes, while monitoring on the surface requires special attention to be paid to the stability conditions of the surface above old mine works and hydrogeological conditions in the area above the extraction or impact area. A practical example of the monitoring program that needs to be made when a mine closes is given in the article. The program covers areas, presents the ways and methods of measurement, as well as reporting of the measurements. The analysis procedure of already existing measurements, which need to be analyzed and included in the preparation of the monitoring program, is also presented.
\end{abstract}

Key words: monitoring, stability, extraction area, measurement method

\section{Povzetek}

Po opustitvi rudarskih del in trajnem zaprtju rudnika mora nosilec rudarske pravice skladno z veljavno zakonodajo in $\mathrm{z}$ namenom nadzorovanja pridobivalnega prostora izvajati monitoring. Monitoring obsega spremljavo sprememb, ki so nastale ob izvajanju rudarskih del, tako na površini kot pod njo.

V članku so predstavljena izhodišča za izdelavo programa monitoringa po opustitvi rudarskih del. Pridobivanje mineralne surovine v podzemnem rudniku ima za posledico različne vplive na površino in podzemni prostor. Področja oziroma segmenti monitoringa so $\mathrm{v}$ nalogi razdeljeni v dva dela. Jamski del spremljave obsega spremljavo geomehanskih, klimatskih in hidrogeoloških sprememb. Podobno je potrebno predvideti spremljavo dogajanj na površini, kjer je posebna pozornost posvečena stabilnostnim razmeram površine nad jamskimi deli in hidrogeološkim razmeram v območju pridobivalnega prostora oziroma vplivnem območju. Podan je praktičen prikaz programa monitoringa, ki ga je potrebno izdelati ob zaprtju rudnika. V programu so zajeta področja, predstavljeni načini in metode meritev, kakor tudi poročanje o le teh. Prav tako je predstavljen postopek analize že obstoječih meritev, ki jih je potrebno analizirati in vključiti v izdelavo programa monitoringa.

Ključne besede: monitoring, stabilnost, pridobivalni prostor, metoda meritev 


\section{Introduction}

In the field of mining, during its operation and gradual closure, it is necessary to prepare technical mining documentation in the form of projects and programs to monitor the effects of mining on the underground and surface areas for different periods [1]. With regard to the type of mining and the method of closing the mine, further impact monitoring is required. For this, it is necessary to develop a program on which further monitoring and measurements will be based [1].

Due to montangeological conditions, it is not yet possible to leave underground areas completely unattended during the mine closure phase. Based on previous experience, it is indicated by both geomechanical and hydrological developments in the areas of operation of individual mines that the impact trend does not slow down with the closure of the mine, and hence further monitoring is needed. The effects of mining are manifested on the surface in the form of deformations, hydrological phenomena, and stability effects on structures or terrain configuration $[1,2]$.

Generally, mines already have an established system for monitoring their impacts at the extraction area, in the form of a concession deed and a contract. This system needs to be analyzed, updated, and give detailed further proce- dures for monitoring. In this way, we can determine which areas are suitable for further use in other fields and which areas need continued protection.

A network of observations must be established in the wider area of the mine throughout the mining process as well as during its gradual closure. This covers the areas both below and above the surface of the entire extraction area, but they are divided by individual excavation fields or caves. Impact measurements are carried out on individual segments, such as visual observations, deformation measurements, and hydrological and geomechanical conditions [1-3].

The measurement results of individual areas and segments need to be combined, comprehensively analyzed, and the basis for further categorization of the impact area given. Measurements and observations of both the underground and surface areas, which contain data on the movements, inflows, flows, and levels of groundwater and surface water, as well as changes in the geomechanical characteristics of the area, must be collected and analyzed. The results of the analyses must be presented in the monitoring program in such a way that it is possible to categorize the impacts, which are divided into individual categories.

Based on the measurement results analysis, it is necessary to determine the critical or limit

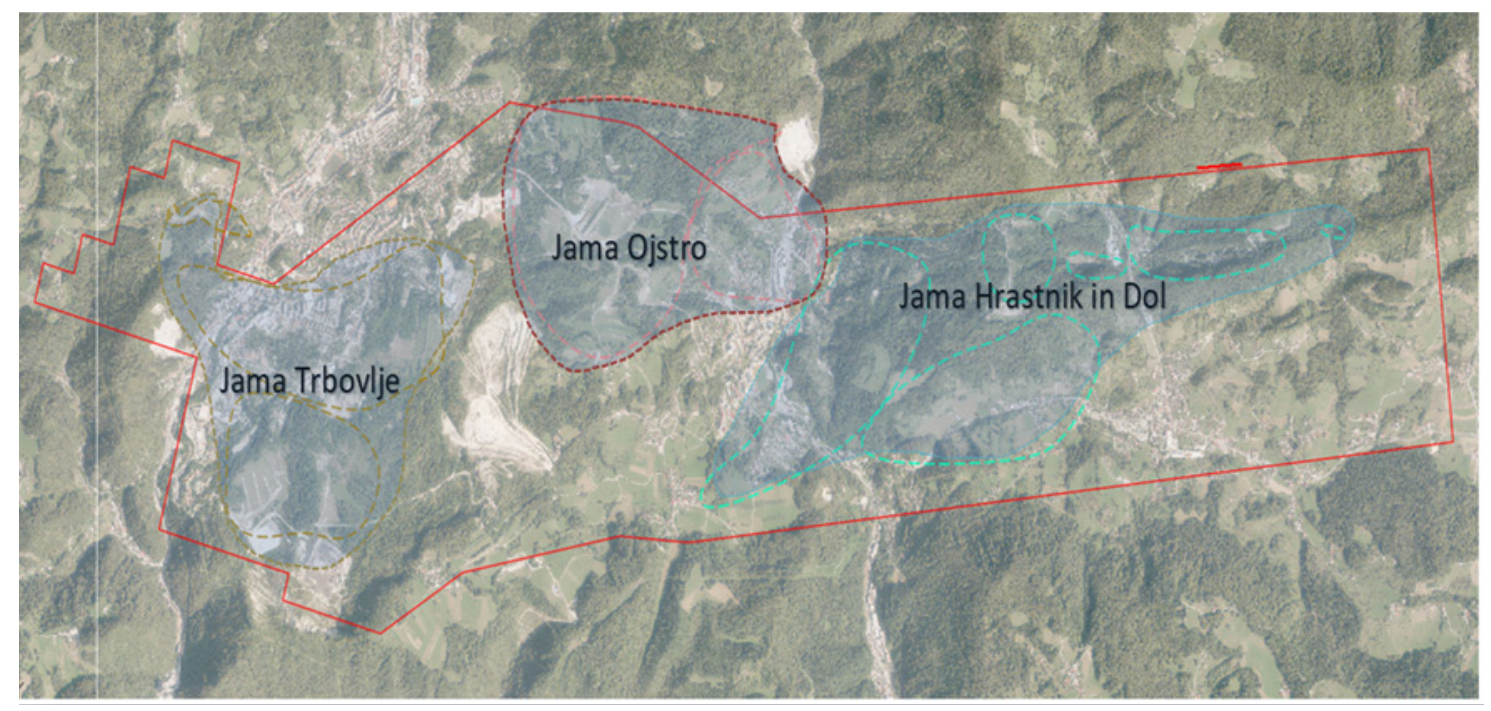

Figure 1: Depiction of the RTH extraction area and areas of underground work [1]. 
values of the individual observation parameters for movements, flows or water levels, and the geomechanical characteristics of the materials for each category [2].

A practical example of preparing a monitoring program for the RTH coal mine is shown in the article.

The monitoring program includes monitoring the impacts of mining both in the underground and on the surface area of the RTH extraction area. The underground part comprises four caves, while the surface area covers the entire extraction area through two municipalities. The area we address in this article is both an erosion and an impact area.

The preparation of the monitoring program considers all applicable legislation, rules, standards, and existing technical documentation, as well as geological and geotechnical data obtained from previous measurements in this area.

\section{Monitoring system}

The monitoring activities prescribed by the program must be carried out on the underground part and on the surface by individual segments and later defined into categories based on the analysis of the results. The segments are as follows [1-3]:

Visual inspections on the underground and surface areas;

- Underground climate control;

- Geotechnical measurements of underground structures and of the surface area;

- Hydrological measurements in the mine and on the surface;

- Surface movement measurements.

The measurement methods and equipment are defined in the monitoring program for individual observations and segments of measurements. Consequently, and with regard to the nature of the observed area, the specificity of an individual measurement and observation, and the accuracy and frequency of an individual measurement are determined.

The monitoring program defines the interpretation of the results of individual areas and segments. Furthermore, it defines how the measurement results are placed in the impact categorization.

Visual inspections must be carried out in the open sections of individual caves and on the entire surface of the extraction area, as prescribed in the monitoring program. Attention should be paid to the permanent structures in the cave, such as transport routes and paths intended for drainage. Surveys of the surface area are carried out with patrols, which can be a problem, as some areas are more difficult to access. During patrols of the underground parts, climate measurements are performed by recording possible gases, the temperature, and wind direction and strength.

Geotechnical measurements in the underground and surface areas are carried out in accordance with the program and include the following [1]:

- Deformation measurements of underground areas (extensometers, dynamometers, and measuring anchors);

- Surface stability measurements (inclinometers);

- Hydrogeological measurements in the mine (measurements of flows, inflows, and outflows of water);

- Hydrogeological measurements on the surface (piezometers, flows and water levels, physical and chemical properties of water);

- Surface movement measurements (classical terrestrial methods, GNSS, UAVs).

Figure 2 shows the surface deformations due to underground works, which must be monitored in accordance with the monitoring program by using inclination measurements and geodetic methods.

When surveying surface movements, classical geodetic and GNSS equipment are used, by which the measurement methods and procedures are known. In recent times, there has been potential in using unmanned aerial vehicles, which make visual and measurement observations much easier. However, they cannot be used for creating images of the entire RTH extraction space, as a large part of the area is inhabited, and at the same time there would be too much data captured, which would be difficult to process. This method is suitable for hard-to-reach areas, where an individual sur- 
Table 1: The scope of unmanned aerial vehicle uses in mining [4].

\begin{tabular}{ccc} 
Surface mines & Underground mines & Closed mines \\
\hline - Mine operation & - Geotechnical characterization & - Land subsidence monitoring \\
\hline - 3D mapping & - Rock size distribution & - Recultivation \\
\hline - Bank stability & - Monitoring and measurement of gases & - Surface mapping \\
\hline - Mine safety & - Mine rescuing & - Detecting gas pockets \\
\hline - Structure monitoring & & - Acid leakage monitoring \\
\hline - Facility management & & \\
\hline
\end{tabular}

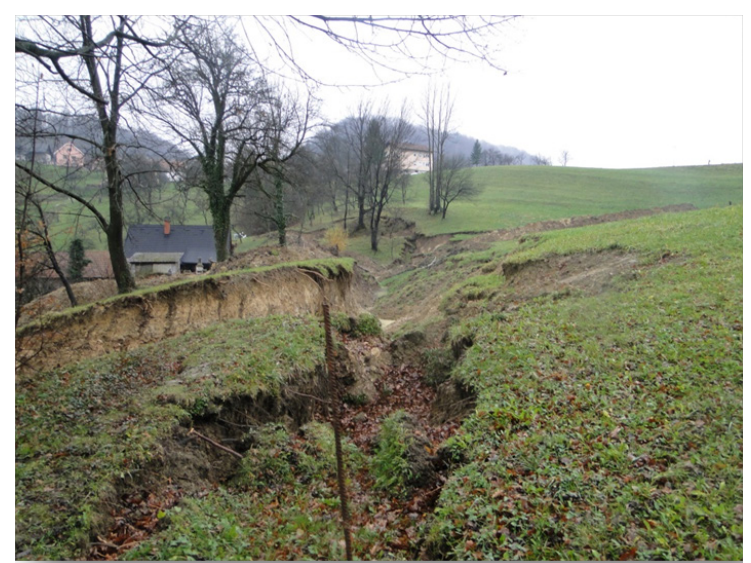

Figure 2: Surface deformations.

face could be inspected visually and measured in a relatively short time.

\section{Alternative observation method}

Observations of surface changes both underground and on the surface can be carried out with relatively simple newer methods of monitoring and observations using unmanned aerial vehicles. Recently, this method has become a more established one and for which we can determine relative as well as absolute changes with the help of surface model analyses. The problem that arises when using aerial recordings is in the large amount of data, accuracy, and relatively demanding equipment. Furthermore, these methods may be limited due to legislation that restricts the use of unmanned aerial vehicles in urban areas.
Recordings of the state of the area in different periods can be captured with advanced aerial photography technology using unmanned aerial vehicles, which capture point clouds and photo-document the state of the surface. The results of aerial photography are presented in various visualization forms such as point clouds, 3D area models (digital surface model) and DOF (digital ortho photo). We combine all this in AutoCAD Civil 3D, where we get a high-quality base for calculating masses. Table 1 gives the areas where unmanned aerial vehicles are used in mining and Figure 3 shows examples of some unmanned aerial vehicles.

Due to its content and method of processing, observations with the help of unmanned aerial vehicles interfere with the field of GIS (Geographic Information System) or computer-aided spatial information systems, which provide a modern management, organizational, and business basis for capturing, storing, searching, processing, analyzing, displaying, and disseminating spatial data. The emphasis is on various analyses of spatial data [5].

Aerial photography with unmanned aerial vehicles means a noncontact photogrammetric capture of spatial data. The results of the overflight are aerial photographs of the area taken with a digital camera attached to the vehicle. Due to image matching, individual photos must overlap by at least $65 \%$. Using image matching and photogrammetric methods, we can orient the bunch of images along both the horizontal and height axes. Thus, we obtain volume data in a relative coordinate system, which is oriented into the national coordinate system with the help of classical or GNSS technologies [4]. 


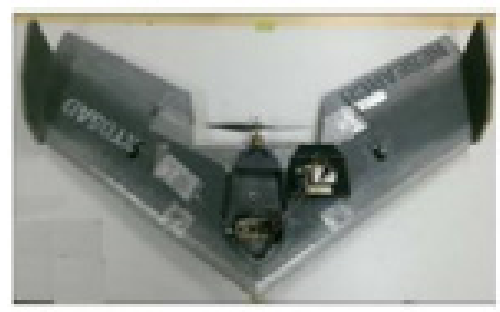

a

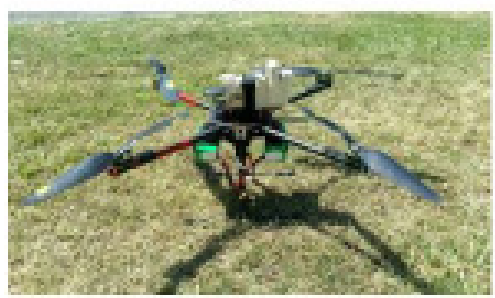

d

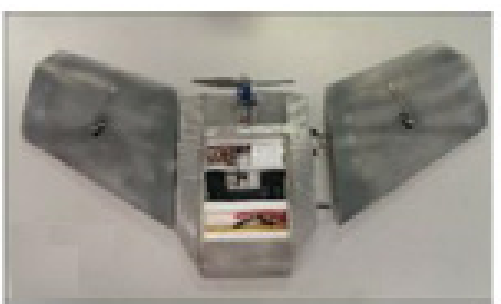

b

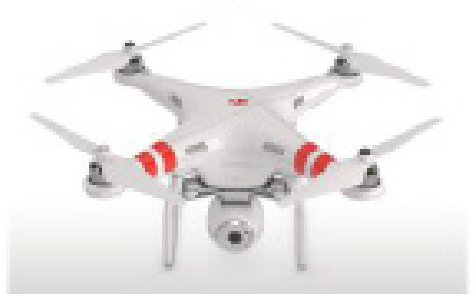

e



c



f

Figure 3: Unmanned aerial vehicles suitable for surface use: (A) Teklite, (B) GoSurv, (C) Swamp Fox, (D) Quadcopter, (E) Phantom 2 Vision+, and (F) Aeryon Scout [4].

Field data, measured with an unmanned aerial vehicle within different periods, is imported into AutoCAD CIVIL 3D as a cloud of points. Surface modeling is performed using the geostatic surface adjustment method.

The basic idea is in the detailed recognition of some characteristics of the general course of the surface, which is to be determined from the data. These findings are used to estimate and determine values on missing or undefined parts of the surface. In the kriging method, the most important criterion is the smoothness of the surface, which we try to ensure by using statistical methods. Kriging is not a method that can be used automatically and without understanding the given area, as it requires the user to be present and actively participate in certain decisions [6].

As a result of modeling individual captured images, surface models of different periods (DMRs) are obtained [7]. We attach these images on the same points on the edges, which enables us to compare the volumes between different time measurements. AutoCAD CIVIL 3D allows us to compare different surface models as a composite grid of points in the base model (existing state) and comparative models (derived state) [8]. The volume of the mathematical formation of the surface difference is defined by the exact height differences of any point of the model. Both the capturing method and the DMR modeling method must be defined in advance by the monitoring program and are conditioned by the terrain configuration itself [9].

\section{Monitoring area categorization}

The monitoring area categorization parameters are based on the results and interpretation of the impact measurements of individual segments and areas [10]. The combined data of individual segments and areas are comprehensively analyzed, and the impact area categorization basis is provided [11].

The impact categories are as follow:

- Category I: The observation parameters are above the permitted values and cause instability of the terrain, so that further intensive monitoring and ongoing remediation of the area is required.

- Category II: The observation parameters are within the limit values and still affect the lability of the terrain, so further monitoring and, if necessary, remediation of the area is required.

- Category III: The observation parameters are below the limit values and no further observations are required. 
a)

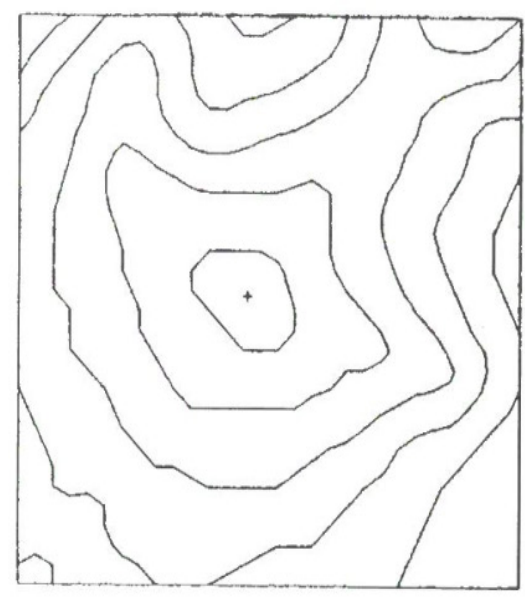

c)

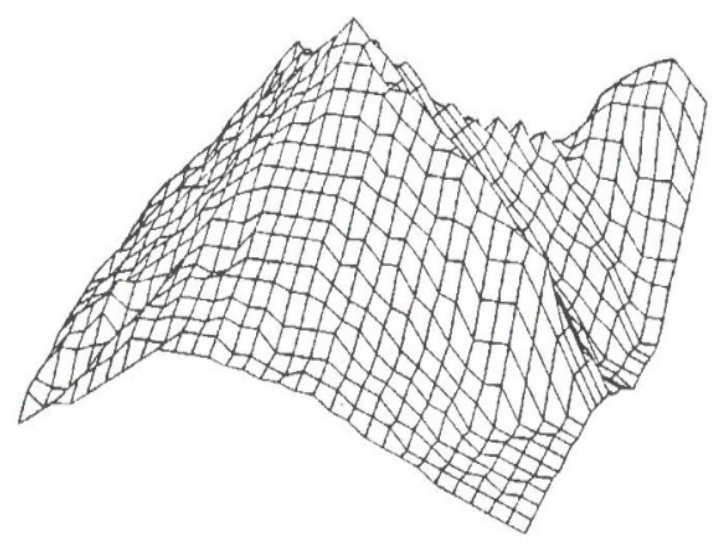

b)

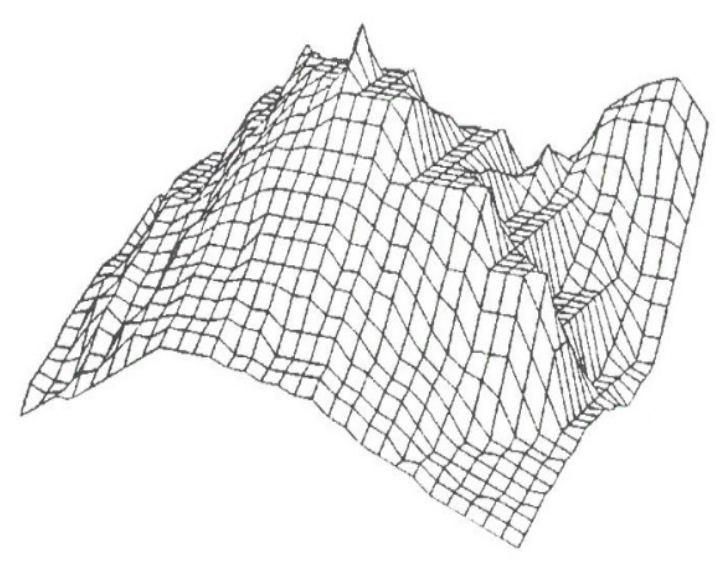

d)

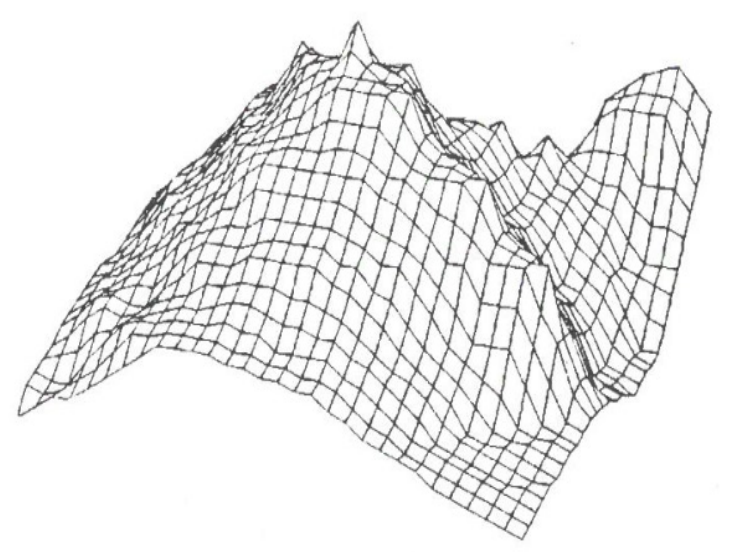

Figure 4. DMR display made with different interpolation algorithms. (A) Isohypse of a hypothetical area. (B) DMR constructed by vertical scanning algorithms. (C) DMR constructed by maximum slope algorithms. (D) DMR produced by the weighted average algorithm [5].

- Category IV: The observation parameters show that the area is suitable for further use for other purposes as well.

A summary of the limits of the individual categories for movements and inclinations is given in Table 2.

The interpretation of measurements must be carried out based on the periodic measurement reports of individual segments, performed by a professionally trained team, which also leads and coordinates the measurements [12].

The purpose of the measurements is to follow the time development of deformations on the surface, in the surface layers in critical areas, as well as in the entire extraction area. It is necessary to unambiguously determine the stability situation in populated areas, both within the security pillars and beyond.

The basic criterion for determining additional measurements is the time development of the measured parameters of all measurements. Since the measurements are carried out on different geological surfaces, it is impossible to give a general criterion of the permitted movement of the terrain in length units where it is necessary to act with mining or construction works. 
Table 2: Impact categorization [1].

\section{Category [Limit]}

\begin{tabular}{ccccc}
\hline Segment & I & II & III & IV \\
\hline $\begin{array}{c}\text { Movement } \\
\text { measurements }\end{array}$ & $\begin{array}{c}\text { Above } 50 \mathrm{~mm} \text {, also new } \\
\text { measurement sites }\end{array}$ & $\begin{array}{c}\text { Up to } 50 \mathrm{~mm} \text { and } \\
\text { deformation trend }\end{array}$ & $\begin{array}{c}\text { Up to } 20 \mathrm{~mm} \text { and } \\
\text { deformation trend }\end{array}$ & $\begin{array}{c}\text { Below } \\
20 \mathrm{~mm}\end{array}$ \\
\hline Inclinometer & Above $50 \mathrm{~mm}$, also new & Up to $50 \mathrm{~mm}$ and & Up to $20 \mathrm{~mm}$ and & Below \\
measurements & measurement sites & deformation trend & deformation trend & $10 \mathrm{~mm}$ \\
\hline
\end{tabular}

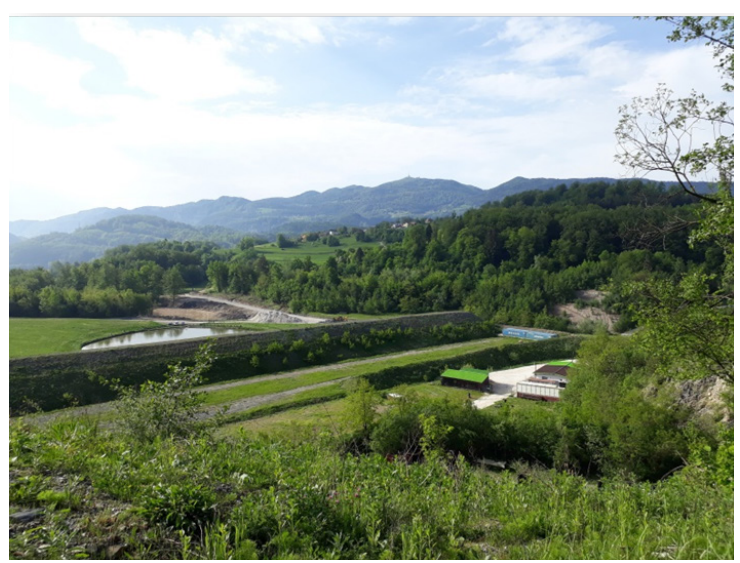

Figure 5: Remediated area above the mining area.

\section{Conclusion}

To monitor the impacts of mining in the wider area of the mine, it is necessary to prepare technical mining documentation in the form of a monitoring program during its operation and during the implementation of its gradual closure.

A network of observations must be established in the wider area of the mine throughout the mining process and the gradual closure of the mine. This covers the area both below the surface and on the surface of the entire extraction area, by individual excavation fields or caves. Impact measurements are carried out by individual segments, such as visual observations, deformation measurements, and hydrological and geomechanical conditions.

Based on the analysis of the measurement results, critical or limit values of individual observation parameters for movements, flows or water levels, and geomechanical characteristics of materials are determined for each category and are as follows:

Category I: The observation parameters are above the permitted values and cause instability of the terrain, so that further intensive monitoring and ongoing remediation of the area is required.

Category II: The observation parameters are within the limit values and still affect the lability of the terrain, so further monitoring and, if necessary, remediation of the area is required. Category III: The observation parameters are below the limit values and no further observations are required.

Category IV: The observation parameters show that the area is suitable for further use for other purposes as well.

The article shows a practical example of preparing a monitoring program for the RTH coal mine. The monitoring program analyzes the performed works and defines the areas where the works are still being carried out or have already been carried out, and then adjusts the monitoring activities accordingly.

Measurement methods and equipment must be defined in the monitoring program for individual observations or measurement segments. Consequently, and with regard to the nature of the observed area, the specificity of individual measurement methods and observations, and the accuracy and frequency of individual measurements are determined.

The monitoring program also defines the interpretation of the results of individual areas and segments and predicts the way in which the measurement results must be placed in the impact categorization. 


\section{References}

[1] Hribar, T. (2018): Program monitoringa na območju Pridobivalnega prostora RTH za obdobje 2018 do 2023. IRGO: Ljubljana, $106 \mathrm{p}$.

[2] RP (1996): Meritev posedkov in premikov ter določitev ukrepov v primeru anomalij, št. 21/409/0296/LF. IRGO: Ljubljana.

[3] Poročilo o izvedbi študije (2001): Dvigovanje podtalnice po prenehanju črpanja vode v AB polju jame Trbovlje, št. GV7210 641 IS/210 610. IRGO: Ljubljana.

[4] Shahmoradi, J., Talebi, E., Raghanchi, P., Hassanalian, M. (2020): A Comprehensive review of applications of drone technology in the mining industry. Drones, 4(3), pp. 2-25, DOI:10.3390/drones4030034.

[5] Kvamme, K., Oštir-Sedej, K., Stančič, Z., Šumrada, R. (1997): Geografski informacijski sistemi. Znanstvenoraziskovalni center SAZU, $476 \mathrm{p}$.

[6] Zimmerman, D.A., De Marsily, G., Gotway, C.A., Marietta, M.G., Axness, C.L., Beauheim, R.L., Bras, R.L., Carrera, J., Dagan, G., Davies, P.B., Gallegos, D.P., Galli, A., Gómez-Hernández, J., Grindrod, P., Gutjahr, A.L., Kitanidis, P.K., Lavenue, A.M., McLaughlin, D., Neuman, S.P., Ramarao, B.S., Ravenne, C., Rubin, Y. (1998): A comparison of seven geostatistically based inverse approaches to estimate transmissivities for modeling advective transport by groundwater flow. Water Resources Research, 34(6), pp. 1373-1413.

[7] Balenović, I., Marjanović, H., Vuletic, D. (2015): Quality assessment of high density digital surface model over different land cover classes. Periodicum Biologorum, 117(4), pp. 459-470.
[8] Hargitai, H., Willner, K., Buchroithner, M. (2019): Methods in planetary topographic mapping: A review. In: Planetary Cartography and GIS, Horgitai, H. (ed.). Springer International Publishing, pp. 147-174.

[9] James, M.R., Robson, S. (2012): Straightforward reconstruction of 3D surfaces and topography with a camera: Accuracy and geoscience application. Journal of Geophysical Research: Earth Surface, 117(F3), pp. 1-17.

[10] Pardo, J.M., Lozano, A., Herrera, G., Mulas, J., Rodríguez, Á. (2013): Instrumental monitoring of the subsidence due to groundwater withdrawal in the city of Murcia (Spain). Environmental Earth Sciences, 70(5), pp. 1957-1963.

[11] Tomás, R., Cano, M., García-Barba, J., Vicente, F., Herrera, G., Lopez-Sanchez, J.M., Mallorquí, J.J. (2013): Monitoring an earthfill dam using differential SAR interferometry: La Pedrera dam, Alicante, Spain. Engineering Geology, 157, pp. 21-32.

[12] Herrera, G., Álvarez-Fernández, M.I., Tomás, R., González-Nicieza, C., López-Sánchez, J.M., Álvarez-Vigil, A.E. (2012): Forensic analysis of buildings affected by mining subsidence based on Differential Interferometry (Part III). Engineering Failure Analysis, 24, pp. 67-76. 